\title{
(息)
}

Citation:

Schiffer, A (2016) Empowered, excited, or disenfranchised? Unveiling issues of energy access inequality and resource dependency in The Gambia. Energy Research and Social Science. ISSN 2214-6296 DOI: https://doi.org/10.1016/j.erss.2016.04.011

Link to Leeds Beckett Repository record:

https://eprints.leedsbeckett.ac.uk/id/eprint/5202/

Document Version:

Article (Accepted Version)

The aim of the Leeds Beckett Repository is to provide open access to our research, as required by funder policies and permitted by publishers and copyright law.

The Leeds Beckett repository holds a wide range of publications, each of which has been checked for copyright and the relevant embargo period has been applied by the Research Services team.

We operate on a standard take-down policy. If you are the author or publisher of an output and you would like it removed from the repository, please contact us and we will investigate on a case-by-case basis.

Each thesis in the repository has been cleared where necessary by the author for third party copyright. If you would like a thesis to be removed from the repository or believe there is an issue with copyright, please contact us on openaccess@leedsbeckett.ac.uk and we will investigate on a case-by-case basis. 


\title{
Empowered, excited, or disenfranchised? Unveiling issues of energy access inequality and resource dependency in The Gambia
}

\section{Anne Schiffer}

School of Planning, Architecture and Civil Engineering, Queen's University Belfast, University Rd.,

Belfast BT7 1NN, United Kingdom

Energy Research \& Social Science 18 (2016) 50-61 https://doi.org/10.1016/j.erss.2016.04.011

\begin{abstract}
The study assesses the impact of energy service provision in The Gambian settlement of Kartong through a qualitative study that employs immersion and mapping methods. In time for the 2013 Ramadan celebrations, the first 19 households are connected to a regional electricity grid. Shortly after a bus service is introduced that runs from Kartong to Banjul, the capital city of The Gambia. It provides a reliable alternative to so-called bush taxis that operate without a set schedule. While the provision of energy services including electricity and transport is recognized as important in supporting people's livelihoods, it poses questions about a shift from energy self-sufficiency to increased dependency on outside resources. Locally there is also an increased emphasis regarding inequality in accessing these services. For example, grid infrastructure is currently limited to the longer established parts of Kartong, putting households on the edge of the settlement in a disadvantaged position.
\end{abstract}

\section{Keywords}

Design anthropology; Energy metabolism; Community energy; Mapping.

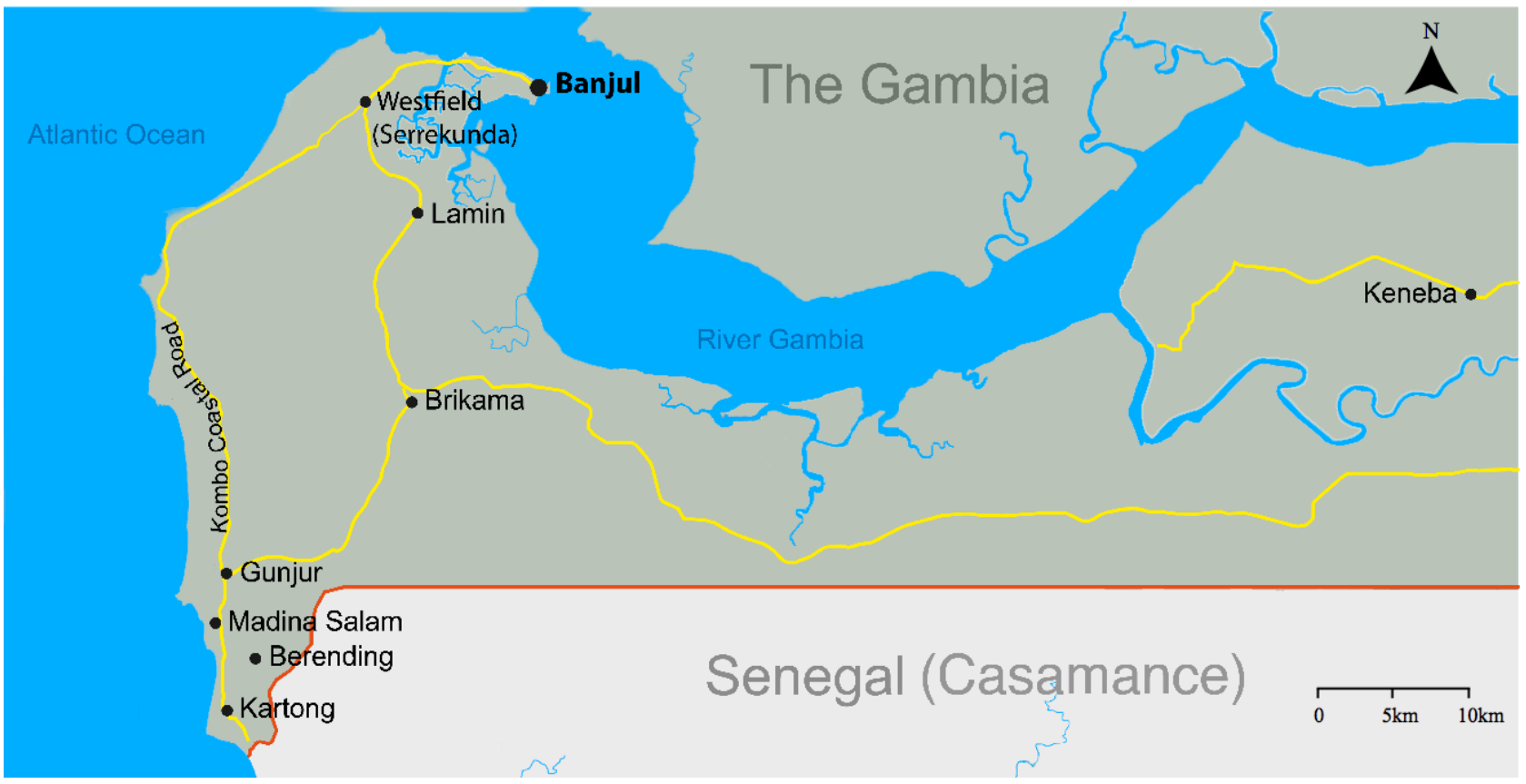

Fig. 1 Regional map relevant towns in The Gambia (Source: Author's own work). 


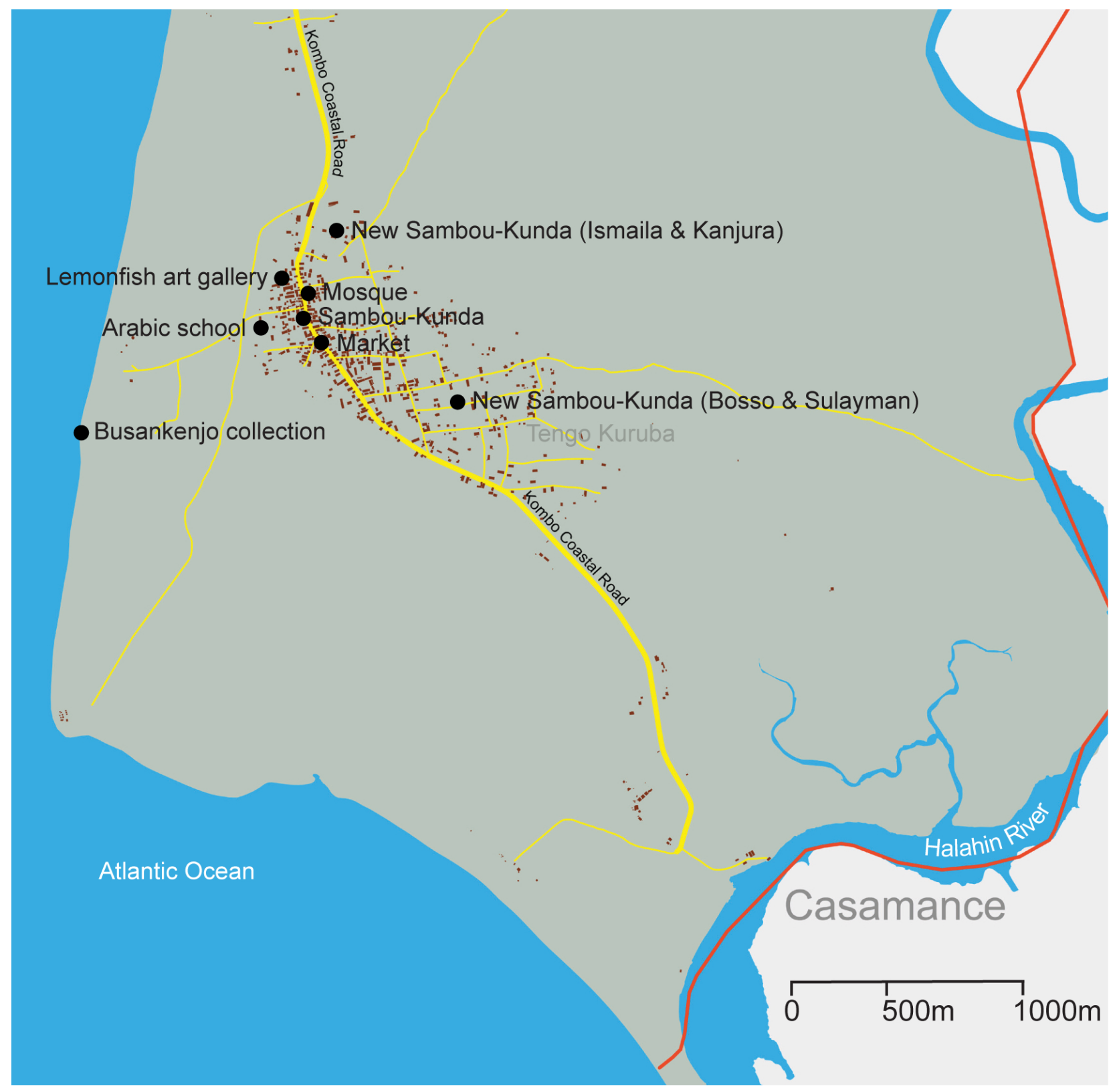

Fig. 2 Kartong map Relevant place in Kartong (Source: Author's own work).

\section{Introduction}

Access to modern energy services provided through national infrastructure projects is often associated with increased living standards. The same is true for The Gambian coastal settlement of Kartong where grid electricity and motorised transport are gaining importance.

However, mapping and immersion in Kartong provide in-depth understanding of the local energy context which also highlights issues of increasing resource dependence as well as local inequalities.
Following an introduction to the energy metabolism framework, the paper presents the methodological approach of the research. Research results from immersion and mapping are presented in a contextual narrative "A day in the life of Sambou-Kunda", which was written during the rainy season in August 2013. A visit to Kartong during the dry season the following April, prompted a follow-up story "Eight months later", which is also included here. Both narratives centre around the Sambou family that hosted me during visits to Kartong. 
The narratives are followed by a brief discussion section and conclusion, which highlights the fact that human insights gathered through immersion can offer deeper and important insights into local energy metabolisms that may be overlooked by topdown approaches to energy development.

\section{Urban metabolism as a framework for assessing the sustainability of energy development}

Underlying all human activities are forms of energy that allow us to move resources and people, heat homes and manufacture goods. Even the metabolic processes and physical work of the human body rely on energy sourced from food or stored as protein, fat and carbohydrates. Energy is commonly defined as the 'ability (or capacity) to do work.' While policy makers tend to shy away from this broad definition, it is precisely this ambiguity that urban design relies on, for it is the foundation of understanding the urban metabolism - the holistic flow of resources and services in, out and within the urban environment.

The urban metabolism is often compared with metabolic processes of the natural system "in which every output which is discharged by an organism also becomes an input which renews and sustains the continuity of the whole living environment of which it is a part" $[1,2]$, making it inherently circular. Like the 'cradle to cradle' approach proposed by McDonough and Braungart in relation to manufactured goods [3], circular metabolisms are put at a par with sustainable whereas linear metabolisms are wasteful, polluting and unsustainable.

The 'energy metabolism' is inextricably linked to all other metabolic processes and human activities in the urban environment and is therefore paramount to tackling issues of sustainability. However, a reduction of energy metabolisms to quantifiable resource inputs, outputs and their economic value as measured in monetary terms happens "at the expense of understanding qualitative differences $[4,5]$."
Perhaps the most basic form of a circular energy metabolism is in the context of people sustainably managing local natural resources such as wood fuel or food as commons [6]. Beyond that there are examples from across the world of citizens owning, managing and sharing energy infrastructure to provide modern energy services at a local level [7, 8, 9]. Here, energy resources such wind and solar are also increasingly seen as common good instead of private property [10].

In a linear energy metabolism communities are typically dependent on fuels and services that are transported over long distances from outside. Governance structures behind linear energy metabolisms tend to be highly centralised $[11,12]$. Here the notion of the consumer is established because people have to pay for commodities and services that are bought in. At the same time these consumers are spatially and psychologically removed from negative environmental and social impacts elsewhere [13]. Girardet [14] states that the world cities of today have the monopoly on the planet's fossil fuels and other resources. Therefore, "the vitality of cities depends on spatial relationships with surrounding hinterlands and global resource webs [15]." The same is true for smaller settlements that predominately rely on external resources.

\section{Methodology}

This research set out to collect and use quantifiable data including land resources to assess the energy metabolism of Kartong. However, through early engagement with the research context, it became clear that quantifiable data was less important in the lives of local people than I had anticipated and it was therefore difficult to source. This is illustrated by the following transcript from a semi-structured interview with Sankung Sambou, the former administrator of the Kartong Association for Responsible Tourism (personal communication 26 October 2010): 
SS: "So.. Kartong is bit densely populated. The population is about you know 3,500 to 5,000 inhabitants."

AS: "That's a big, a big gap."

SS: "Maybe 3,500 - 4,000 ... It could go up to 5,000."

Similarly basic energy surveys of households carried out during the early stages of the research revealed the felt irrelevance of certain quantifiable data in the lives of local people. The most challenging question was always 'how many people live here?' Once, I was asked to return two days later to give people enough time to count the residents of what turned out to be the largest compound in Kartong, which had over 50 residents at the time. Other data such as recent national statistics on average household income or national census data from 2013 was simply not available.

I came to realise that based on my personal histories, values and attitudes, I had bought into what Chambers [16] refers to as the 'NeoNewtonian paradigm.' As he warns, here "'measurement matters' blurs regressively into 'What is measured is what matters' and then 'If it can't be measured, it can't be important', 'If it can't be measured it isn't real', and finally 'If it isn't measured it won't happen.'"

I concluded that a predominately quantitative approach as I had initially envisioned, was not appropriate in this context. Instead, I decided to tackle the analysis of Kartong's energy metabolism by immersing myself in local life. What emerged as a methodology, was a flexible design action research framework in which immersion and mapping provided the desired insights into local energy cultures. Here, storytelling

became a suitable medium to
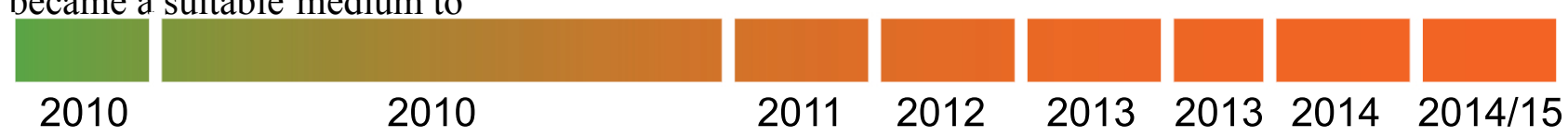

Fig. 3 Field visits to Kartong Time simply present in The Gambia (green) versus time immersed in local life (orange) (Source: Author's own work). 
this research 'seasons' included periods of time that are not just characterised by climate but also cultural and economic factors, for example, the tourist season or Ramadan.

During initial visits to Kartong in 2010 I was able to build relationships that allowed me to stay with the Sambou family during subsequent stays in The Gambia. This enabled me to immerse myself in local life. Shea [25] defines immersion as "any number of ways you spend time with the community" and includes a variety of examples such as taking a neighbourhood tour, conducting focus groups and regular meetings with community leaders. In contrast Laurel [26] talks of "intense immersion" where "spending time observing, interviewing and participating in the multi facets of a subject's life" help to build empathy. In this research immersion is understood as living with and participating in the life of local people, who are not 'subjects' but potential collaborators. Here, my 'embodiment' [27] including equally engaging in physical activity alongside women gardeners was important. It helped me gain empathy as well as challenge negative preconceptions of what it means to work with a toubab - white foreigner.

Where appropriate immersion was supported by other methods including participant observation, semi-structured interviews and visual ethnography [28].

Mapping was used to make visual sense of Kartong's energy metabolism and compliment findings from immersion. Here, the term mapping is used for both geographical maps and other visual abstractions that communicate complex energy information in an accessible manner. Similarly Brook and Dunn [29] define a map as "any form of representation that reveals unseen space, latent conditions or narratives in and of the city." I traced Google satellite images and triangulated or added to information by physically moving through the settlement area and surrounding landscape on the ground.

Mapping also resulted in various visual tools that were later used in discussions with local people which highlighted the increasing linearity of Kartong's energy metabolism.

\section{A day in the life of Sambou- Kunda, ${ }^{1}$ Kartong \\ 4.1 Water}

As the day breaks it is still raining heavily. Empty buckets and wash pans that were placed outside have filled up with rain water overnight. Adama, a little girl in the compound enjoys running through water pouring off the roof into a large bucket. During the rainy season in Kartong, rain water collection helps to compensate for the lack of piped water supply available. In the mid 1990s the European Development Fund (EDF) provided funding and technical assistance for a stand alone piped water supply system for the settlement: solar photovoltaic panels generate electricity to pump water into a 30 cubic metre tank from where it is distributed (using gravitational force) through two separate valves and pipelines to a series of public and private taps across Kartong. Currently, the taps only carry water once every two weeks due to the limited generating capacity of the solar system which produces significantly less energy during the rainy season. Recently the pipelines were extended into Tengo Kuruba, a new settlement on the edge of Kartong, which has further increased demand. The population of Kartong is growing rapidly, currently estimated at around 5,500 residents, which is nearly a $75 \%$ increase of what it was ten years ago $[30,31]$. The size of the storage tank is sufficient to accommodate for the growth but

\footnotetext{
${ }^{1}$ The word kunda means home. Family compounds are usually named after the family that lives there. Therefore the home of the Sambou family is referred to as Sambou-Kunda.
} 
the system is limited by the lack of electricity produced to pump water. The effect that damage to one of the solar panels has had on generating capacity is not clear. Kartonka ${ }^{2}$ Dudu Sanyang volunteers to cycle to the tank to check the water level and open or close the pipes. During the dry season the taps might be open in the mornings and just before dinner every two or three days. Dudu regularly cleans the solar panels that are quickly covered in dust during that time of year. $\mathrm{He}$ has been volunteering his service for over a decade but that does not stop people complaining to him or even his mother about the lack of available water as if it was their fault (Fig. 4).

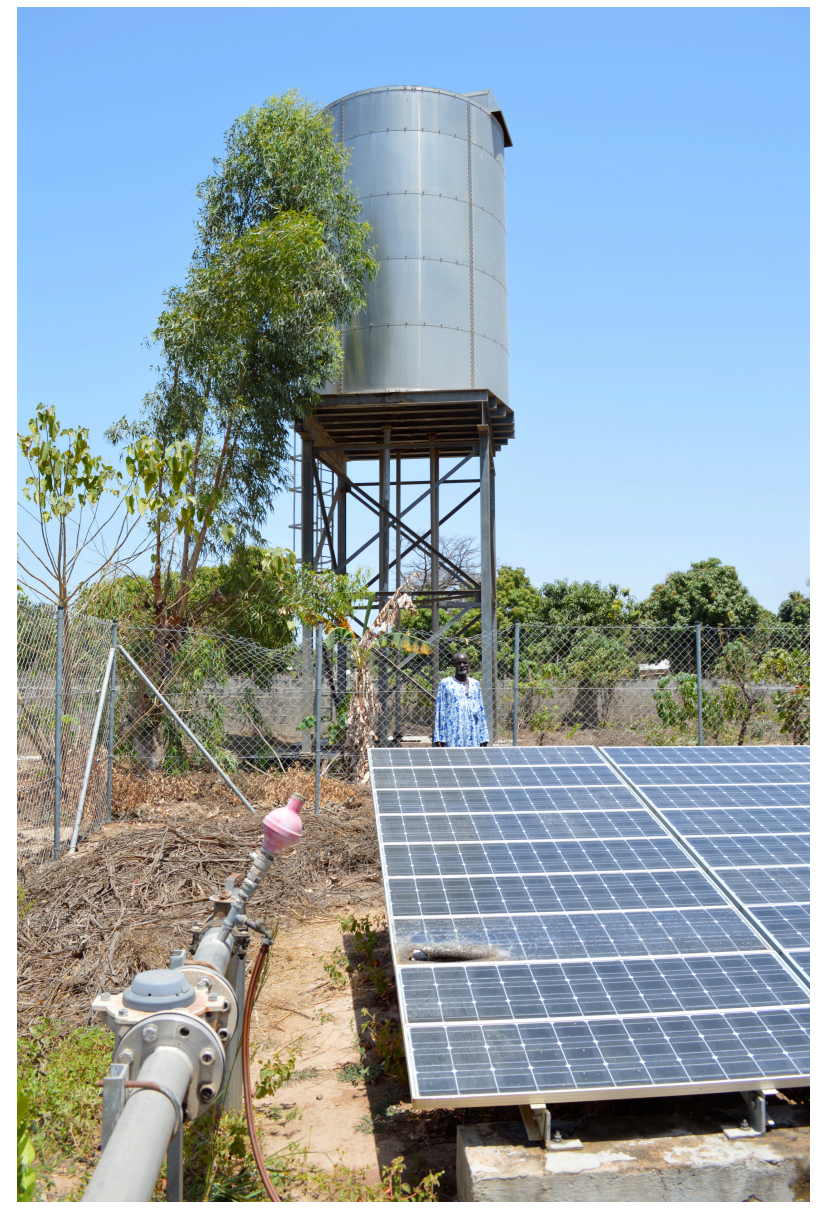

Fig. 4 Kartong central water supply Dudu Sanyang in front of the central water supply's tank and solar system (Source: Author's own photography).

A diesel generator has recently been added to supply additional electricity to pump water into

${ }^{2}$ A kartonka is a person from Kartong. the tank. The generator has to run for five hours, to fill an empty tank, consuming 20L of fuel which cost D800. ${ }^{3}$ Every household in Kartong is supposed to pay a monthly tariff of D10 for the upkeep of the system but this has been difficult to enforce. Instead, funds are raised by installing private taps for a one-off payment of D2,000 and a monthly charge of D50. The local authority, the Village Development Committee (VDC), is responsible for the administration of these funds. In addition, people who are hosting a large event, such as a naming ceremony, are encouraged to donate some money to buy fuel for the generator.

Prior to the EDF installation, a wind powered pump delivered water at a smaller scale. It was erected in the settlement area following the failed attempt to install the wind turbine at the Kartong river site (approximately 1970s) due to a high salt content in the water there. The wind turbine suffered from erosion exacerbated by the 'salty air' coming from the sea and finally fell into disrepair about two years ago. A borehole beneath the turbine is still used by some to pull drinking water.

Sambou-Kunda, like most compounds in Kartong has its own well which carries more water during the rainy season. Simply waiting for the rain to do the work and fill vessels left out in the open is of course easier than pulling it from the well. The rain water will later be used for drinking, cooking, washing clothes, or to perform ablutions before prayers.

Last week was koriteh, a day of prayers and celebrations that marks the end of Ramadan. In preparation of koriteh some of the women and girls from Sambou-Kunda went to fetch water from outside Lemonfish, a local art gallery. There, a hand pump gives access to the 'sweetest' water in Kartong and for special

${ }^{3}$ The Gambian currency is called dalasi. At the time of writing the conversion rate to pound sterling and US dollars and Euros is as follows: $1 \mathrm{D}=£ 0.02$ or $\$ 0.03$ or $€ 0.02$; $£ 1=\mathrm{D} 62$; US\$1=D40; $€ 1=\mathrm{D} 44$. 
occasions, even people from the other side of the settlement area come here to fill buckets and canisters with water to transport back home on their heads or in wheelbarrows.

\subsection{Transport}

It is just after eight o'clock in the morning. Kanjura Sambou has already left for work. Amadou Bansang a relative who also lives in Sambou-Kunda with his wife Omratou "Oumie" Suwane, ${ }^{4}$ meets Ismaila Sambou in front of the compound. They both work in a tourist lodge a few kilometres outside of Kartong to which they cycle together after fetching some breakfast from a local shop.

Sambou-Kunda is situated on the Kombo Coastal Road that connects Kartong, the most southern settlement in The Gambia to Banjul, the country's capital city. The Kombo Coastal Road is the only tarred road in Kartong and before it was built it was difficult for people to travel north. A letter from the alkalo, the traditional leader of the community, to The Gambia's President Yahya Jammeh expresses gratitude for the road and explains how it has enabled people from Kartong to commute to work. Kanjura, who drew up the letter on behalf of the alkalo, works as a lawyer in Banjul and commutes four days a week. He used to travel five days until the president introduced a four day working week in early 2013.

Without the Kombo Coastal Road, Kanjura would likely spend the week away from his family. In contrast, his brother Ousman works as a carpenter and cleaner for the Medical Research Council in Keneba and only spends weekends and holidays in Kartong.

Kartonka Lamin Korteh explains that before the Kombo Coastal Road was constructed: "It will take you 8-10h to travel from Brikama to Kartong in those days. It was very difficult. Sometimes you struggle from
Brikama to get to Gunjur. From Gunjur to Kartong you don't think of a vehicle. You walk on foot (personal communication, 25 April 2014)." Today the same journey might take half an hour by car.

Nonetheless, for Lamin or Kanjura to travel to Banjul on public transport is not straightforward. So called bush taxis travel infrequently as they do not tend to leave before they are full. To get to Banjul, Kanjura has to travel from Kartong to Gunjur, Gunjur to Brikama, Brikama to Westfield, Westfield to Banjul and then walk to his office. It can take several hours to travel approximately $65 \mathrm{~km}$. A few years ago Kanjura owned a car which helped him with his commute. He decided to go back to university and could not afford to keep the vehicle. For him, the continuously rising cost of fuel which leads to rising fares is also a concern. However, last week a new bus service was introduced that runs from Kartong via Brikama to Banjul. The service will officially start operation the day after tomorrow and is expected to provide reliable and affordable transport.

The freedom of movement that allows both Kanjura and Lamin to commute to work and women gardeners in Kartong to sell vegetables at Brikama market also comes with a hazardous dependence: an addiction to fossil fuels. In The Gambia motorised transport is dependent on imported liquid fossil fuels and hence at the mercy of volatile international markets for said commodity [32]. Price hikes in liquid fuel imports almost immediately translate into increased cost at petrol stations and higher transport fares across the country.

Over the coming years Kartong has to carefully balance the benefits of motorised transport and becoming locked into a system that causes economic vulnerability, air pollution, road traffic accidents and contributes to humanmade climate change. However, here as in

\footnotetext{
${ }^{4}$ After marriage women keep their original surname.
} 
other contexts where people aspire to vehicle ownership this is a difficult truth to be heard.

Furthermore the Kombo Coastal Road has enabled mineral extraction on the edge of Kartong. Sand mining originally took place on land between the settlement area and the coast over a number of years. Previously, the proposed re-opening of sand mining caused local uproar. The following letter was published in the Daily Observer newspaper under the title 'A plea from Kartong' [33] in 2009:

"Kindly allow me space to express my unhappiness over plans to relocate the sand mining site back to Kartong. My heart beat with the feeling:

Many youths including myself were saddened not because of anything but a few concerns outlined below: Kartong is a peninsula with very low lands locally known as "faroos". Naturally God erected a high sand hill that served as a protector from the threat of the Atlantic Ocean. A huge amount of this hill has been consumed as a result of the initial mining. Another sand mining would leave us highly vulnerable to the threat of the ocean. Mosquitoes have previously been known to the people of Kartong only in the middle of the rainy season, but since the mining has taken place, we have mosquitoes all year round. This is because the mine serves as a breeding ground for mosquitoes, thereby disturbing our health. Another mining means an increase in the prevalence of these mosquitoes.

The land also serves as a very good land for vegetable gardening for our mothers and sisters, who now have no land or have relocated to other places which are less fertility, thereby causing a high reduction in their produce which they sell to pay school fees for their children and other family needs. Another mining will make them lose more land.

I am now calling on my village development committee to plead with the geology department and other relevant authorities to change this relocation to other places. There is sand available in many places in The Gambia which are under no such threat. We believe that we have at least given our quota for about six years. So please do not come to mine again in Kartong. I wish the geology department my very best of wishes."

The letter points at an area which is inundated by water due to the mining activity and may have led to an increase in mosquitos that carry the malaria parasite. On the other hand it is suggested that the fresh water lakes that have been created are important habitats for birds and may support eco-tourism activities in the region [34].

Last year a new mineral mine was established just north of Kartong. Specific details of what is extracted and processes involved appear largely unknown within the community. Limited employment opportunities appear to be the only direct benefit to local people though operation will soon cease to exist. However, little do people know that in two years from now, tensions will escalate when approximately 30 youths are arrested following protests over renewed mining before being pardoned by president Jammeh. The power of corporate interests enabled by transport infrastructure will all of a sudden become very visible to those demanding justice in Kartong.

It is still raining but the road outside SambouKunda will soon be busy with movement. While motorised transport is important to travel longer distances, within Kartong walking and cycling dominate. Women pass the Sambou-Kunda carrying produce to sell at the market. Some men are braving the weather armed with gardening tools and a man on his bicycle is transporting a covered basked with tapalapa, a baguette like bread, between Kartong and neighbouring Madina Salam or Gunjur.

\subsection{Cooking}

Some of the women and girls are preparing breakfast. They go to the shop to buy filled tapalapas for D12 (or D6 for half). Teenage girl Sarjo Sambou likes chocolate filling. Others prefer njebe, a spicy bean stew, which some women in Kartong prepare freshly in the morning and sell from make-shift stalls outside their compounds. Bread is taken with hot tea or instant Nestle' coffee. Mai Tourey, Sankung's wife, likes to use a small gas cooker to heat water or small meals as it is quicker than firewood or charcoal. She cannot remember the exact cost but says her last bottle of gas, that was bought in Brikama, lasted over three months. Bottled gas is seen as a convenient 
way to heat water by those who can afford it. It reaches Kartong either indirectly through official gas importers such as Gamgas or directly through imports from the neighbouring Casamance region of Senegal. It is worth noting, that the only shop in Kartong that sells bottled gas is foreign-owned with profits leaving the local economy as remittance payments abroad. Therefore, it could be argued that money is leaving the local economy in two ways: first, to buy in gas commodities and, second, as remittance payments.

Mai, a mother of three boys and teacher at the local Arabic school shares the responsibility for preparing lunch and dinner with other women in Sambou-Kunda. Mai's younger sister Njima is currently visiting from Senegal and helps her with household chores.

The start to the day has been slow due to the continuous rain. As lunchtime approaches, the traffic outside Sambou-Kunda is slowing down. In some compounds people are already huddling round bowls of rice. Today Yoko, Ousman's eldest daughter is cooking lunch. There are several individual kitchen areas but for communal cooking women use a kitchen outhouse at the back of Sambou-Kunda. Big meals are prepared on an open wood fire with firewood collected from the land around Kartong. The traditional method is simply to put a metal pot on three stones, leaving enough room underneath to slide wooden sticks in and out to control the intensity of the fire as the sticks burn. The kitchen outhouse fills with dense smoke that makes women and children cough. It also protects food from cats that roam alongside walls and roofs hoping to snatch bits of fish or chicken. Perhaps this is one reason why women cook in this environment despite the negative impacts on their health [35]. Smaller meals are often prepared on parts of the veranda that is covered by a roof or in backyards belonging to individual households that make up Sambou-Kunda.
Binta Jassi, Halli Jammeh and Oumie have been processing busankenjo, a type of shellfish they collect from the beach. The women use a charcoal stove to boil the shells so they open and the meat can easily be extracted. Yesterday Binta Jassi also collected rotten fish from the beach. Bintou who carried the smelly fish home together with little Jeneba took a back road to Sambou-Kunda. She felt embarrassed and did not want people to see her carrying the rotten fish. However, Binta Jassi who is one of the elders in the compound still knows how to make use of it. This morning she cleaned the fish, covered it in salt and left it to dry out under the veranda. When the rain stops she will move it into the sun. This process restores the meat to a state where it can be safely consumed whilst at the same time preserving it. Halli and Binta Jassi are still fasting. Therefore they do not stop for lunch but continue to process busankenjo until the job is done. They preserve some of the meat with the same technique Binta Jassi used for the rotten fish. Later in the afternoon, when the tide is low, the women will return to the beach with Jeneba to continue their search. The women cannot swim. They will work standing in the water alongside groups of other women from Kartong until the sun is about to set and they can go home to break their fast.

\subsection{Land and people}

Geographically, Kartong is surrounded by water on three sides - the Atlantic Ocean to the west and the Halahin River in the east and south. The Halahin River also forms the natural border with Senegal. Originally Kartong land bordered with that of Gunjur to the north. However, land between the two communities has since been allocated for the more recent settlements of Madina Salam and Berending that now forms the northern border with Kartong.

Traditionally Kartong land is owned by four settler families: Manneh, Tourey, and two Jabang families. Their family names also reflect the ethnic groups they belong to 
although intermarriage means that this is no longer strictly the case. As such the Tourey name ethnically belongs to Mandinka people whereas Jabang is traditionally Jola. Kartong has great ethnic diversity though Mandinka and Jola dominate in terms of numbers. Minority groups include Wolof, Serer, Balantas and Karoninka including the Sambou family whose ancestors came to The Gambia from Casamance and are closely related to the Jola. Kartong is also temporary home to people from other parts of The Gambia and west and north African countries such Mauritanian shopkeepers, Senegalese fishermen or Fula who come to Kartong to herd cows during the rainy season. When a Fula roams the land behind Kartong guiding a herd of cows, the wind may carry a melody he plays on his flute. As Sulayman Sambou explains, because the cows cannot talk to him a Fula carries a flute to keep him company.

There is also a small number of European expatriates who own property and mainly come for holidays, manage lodges on the coast or are involved in charities.

People who settled in Kartong after the Manneh, Tourey and Jabang families achieved ownership of land largely through marriage or allocation through personal relationships. A group of Balantas who arrived in Kartong fleeing the Guinea-Bissau independence war were allocated an area of land by the existing community. Increasingly, land is treated as a commodity and sold for profit which can cause conflict where ownership is not clear. As a result, the formalisation of land ownership, in particular written contracts are becoming more common. These replace verbal agreements that would have been sufficient previously. Kanjura predicts increased land grabbing by people from the crowded urban centres of Serrekunda and Brikama to the north as more amenities such electricity are becoming available in Kartong.
A landowner might grant someone else access to his land for agricultural purposes such as rice or vegetable growing. These are seasonal crops and therefore the agreement has to be renewed annually. However, if trees are planted, despite the land owner not having any knowledge of this, Gambian law states that the land may be claimed by the user as rightfully his after a period of five years: In a recent dispute in Kartong several men were arrested for having illegally logged trees in a designated community forest area. As the culprits had planted cashew trees they had to declare in writing that they would claim no ownership of the land at any point in the future. The role of trees is important as their age may be used to determine the period of time the land has been utilised by a particular party.

It quickly becomes clear that land is Kartong's most important physical asset. It provides space to build homes as the population grows. It is a source for free firewood, timber, medicines and grazing for livestock. Furthermore local land (and water) is utilised to cultivate food (Figs. 5 and 6). However, as land is increasingly seen as a commodity and infrastructure can be used to access resources for people elsewhere, traditional land rights are no longer sufficient to protect the interests of local people as seen by the example for mineral mining described earlier on.

\subsection{Food}

Like many women in Kartong, Mai buys produce at the local market and grows her own vegetables during the dry season. Women's vegetable gardens supplement household food supplies either directly or by swapping produce with other women. As such they offer an example of a non-monetary economy that exists alongside monetary systems in The Gambia [36].

In addition vegetable gardens are important to generate income which in many cases is used to pay for children's school fees. Men's fruit orchards on the other hand are established with 


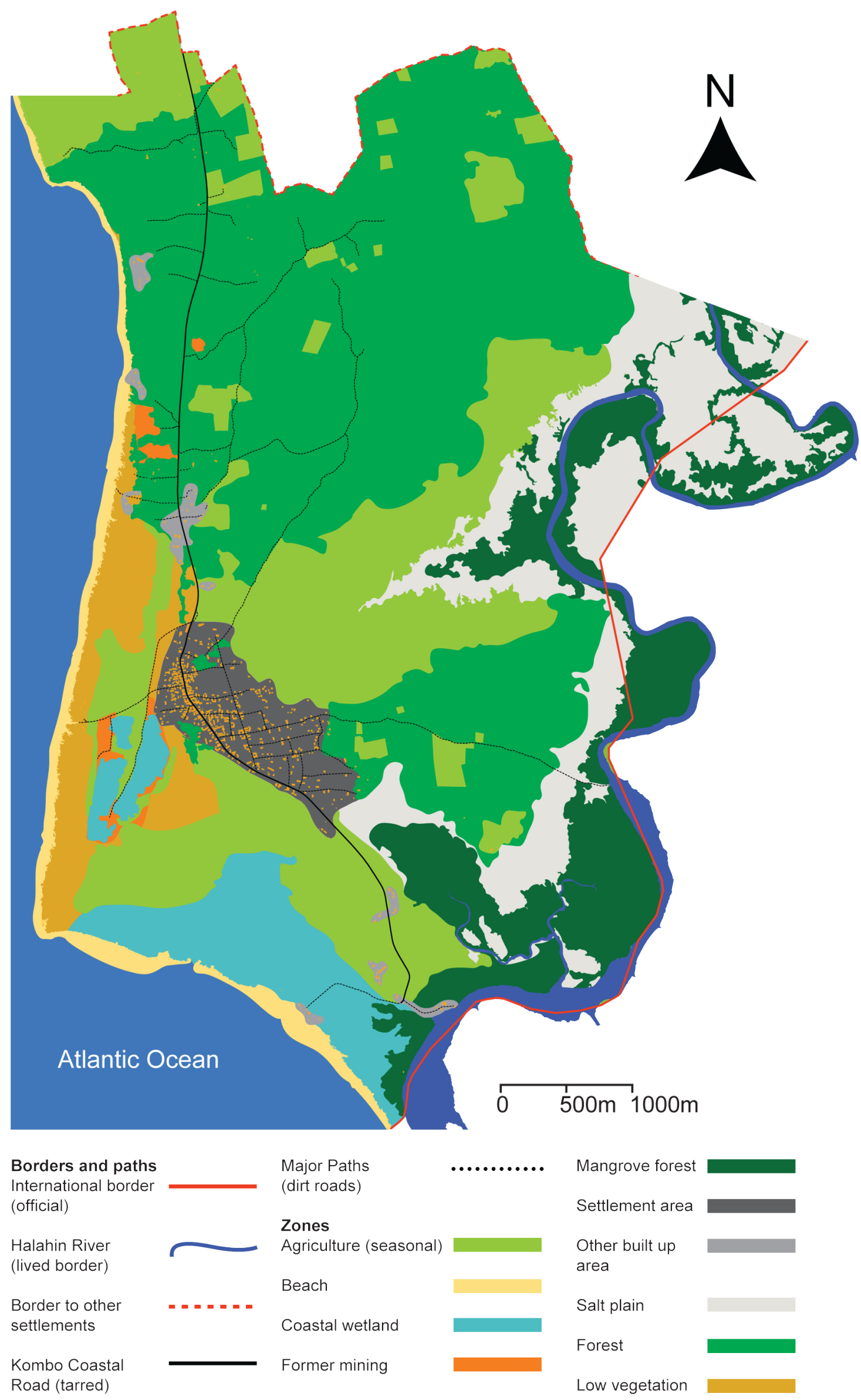

Fig. 5 Kartong map Land use zones (Source: Author's own work). 
the sole purpose of generating income, comparable to other seasonal cash crops such as peanuts. Sankung has planted orange trees on family land located in the bush between Kartong and Berending. He hopes that this will provide stable income in years to come. During the dry season Sankung cycles regularly to his orchard where he drenches the young trees with water he pulls from a well.

Bah-Musa, Sankung's uncle, also has his own orchard. He grows mangoes and recently joined an initiative that supports Gambian growers to export mangos to Europe. To emphasise ownership over fruits Karoninkas sometimes hang a star shaped triangular symbol onto trees. According to local belief, should someone harvest the fruits without permission, it will cause him or her to feel pain, especially in the hand that took the harvest. This can only be redeemed by a ritual that the rightful owner carries out over several consecutive days.

The mango season has however almost finished and most people are now preparing their rice fields. Next week Mai and Bintou will transplant rice from a nursery to a shared paddy near the beach. Local rice production is supplemented by rice from Thailand, Pakistan, or the US. It quickly becomes apparent that economically Kartong like other parts of The Gambia are part of a trade network that spans the globe and not just in terms of food [37]. Fabrics with African patterns are imported from China along with Chinese flip flops, lamps and batteries. Plastic vessels and bottled gas are imported from neighbouring Senegal and second hand clothes from Europe. At the same time, fish sourced in Kartong makes its way to other West African nations and fruit grown locally is sold onto European markets.

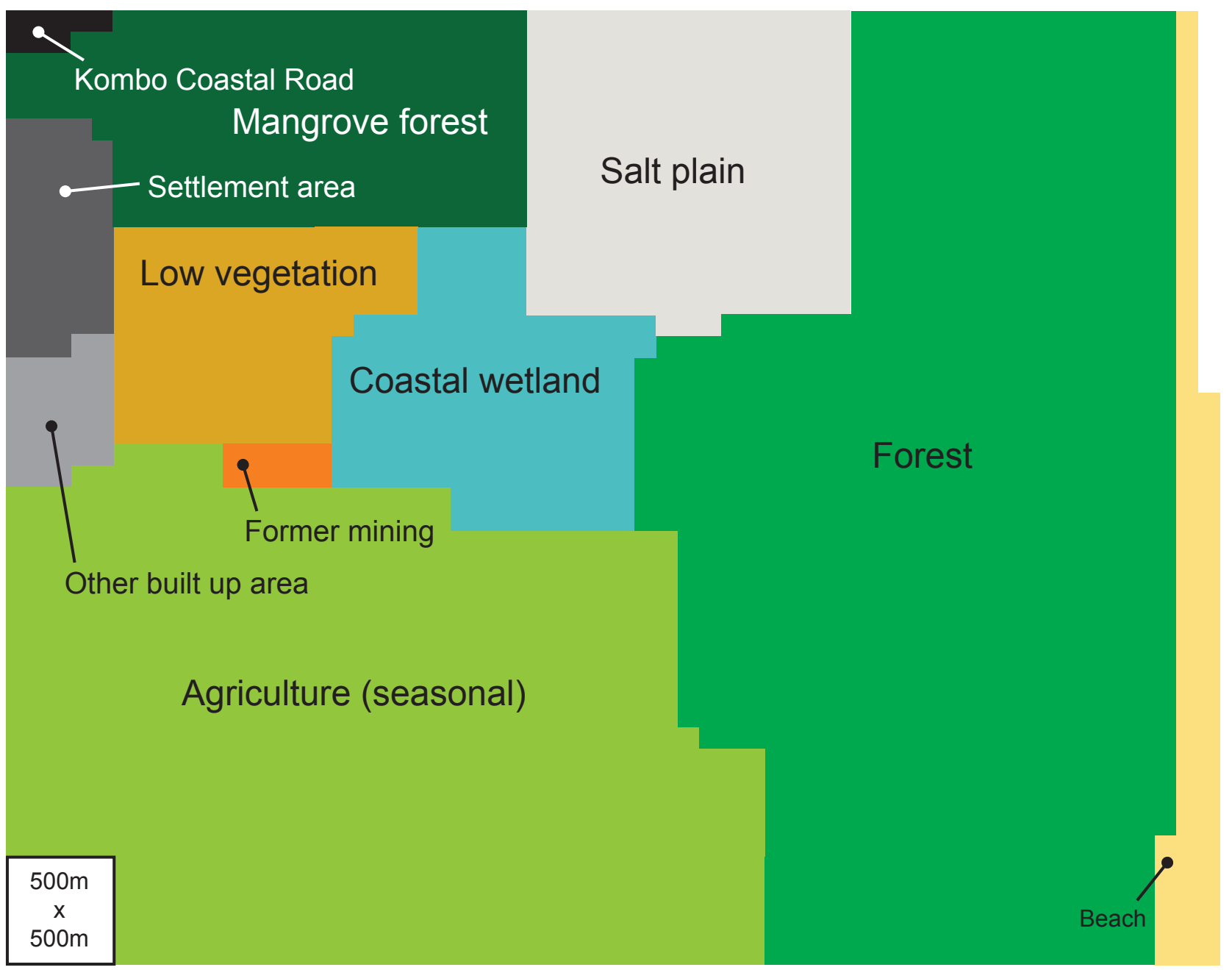

Fig. 6 Kartong land zones A visual tool to discuss local land use (Source: Author's own work). 


\subsection{Charcoal}

In the afternoon the road is busy with children running after bicycle tyres and people walking or cycling. Occasionally a motorised vehicle or a few strolling goats pass by. The shop on the front of Sambou-Kunda has re-opened after lunch. Across the road a mechanic is going about his business fixing bicycles. Like most afternoons, men are chatting in the courtyard of Sambou-Kunda drinking ataya - Chinese gunpowder tea brewed with a high content of sugar. The taste is usually very bitter and sweet at the same time, weakening as up to three pots are prepared with the same tea. There are regular visitors who join in discussions on local politics or simply to chat and drink ataya. Some of the Sambou brothers are involved in local governance issues through membership in local institutions. Badibu Sambou for example is a member of the VDC.

During gatherings at Sambou-Kunda, Sankung and Badibu take it in turns to brew ataya. It is not just about providing people with a drink, ataya is a pastime, a cultural phenomenon that is practiced across the country and beyond. Ataya is brewed on a small charcoal stove using a miniature kettle. The lengthy process of brewing can be observed in compounds and meeting places across Kartong almost any time of day or night. Badibu usually has ataya first thing in the morning sometimes listening to the World Service of the British Broadcasting Corporation on the radio. He has several more glasses during the course of the day and probably one just before retiring for the night.

Charcoal for brewing ataya is usually bought from local shops in small bags costing D2 or collected from one of the many kitchen areas where small quantities are a by-product of cooking with firewood. Shops also sell large D85 sacks the size of rice bags for those who use larger quantities for cooking food on a charcoal stove. Officially, charcoal production in The Gambia is banned under Section 108 of the Forest Act and Regulations 1998. Much of charcoal sold in Kartong is therefore imported from the neighbouring Casamance region but that does not mean that no charcoal is produced locally. When trees are in the way of compound expansions, for example, the landowner may hire a labourer to carry out the clearing work and produce charcoal from felled trees. Instead of a monetary exchange, an amount of charcoal may be negotiated as payment. In some cases the felling of trees requires additional measures. According to local belief trees that are very old are inhabited by a type of spirit. Only Laibo people, an ethnic group related to the Fula, can be hired to perform a ritual that releases the spirit gently. Earlier this year such a ritual was carried out at Ousman and Sulayman Sambou's new compound where a large baobab tree had to be felled.

Kanjura has returned home from work early. His wife Bintou is sitting outside braiding their daughters' hair. The rain has finally stopped and Efo, Halli and Badibu's daughter, has began to iron clothes. She lights charcoal inside the iron to heat it. She says some types of irons need to be continuously fanned to keep the charcoal going but the iron she is using has holes on the side which help air to circulate. Later in the afternoon she will go to work at her mother's rice field.

Efo following into her mother's footsteps is an example of why it is important for women to bear children. Gender roles in Gambian families remain distinct and without a daughter to help her, Halli would likely have to carry out household chores such as cooking, cleaning, washing and ironing clothes as well as working on field all by herself. Children also play an important role to create ties between families and may be given to relatives to strengthen these. For example, Naafi was adopted by Sulayman and his wife Musu although her birth parents are Ousman and Hadiba.

In the evening the road is busy with people walking up and down. Some of the women and girls in Sambou-Kunda set up a make-shift stall on the entrance of the compound where 
they sell a type of home made rice drink in small bags. Sometimes Hadiba sells vegetables from the garden here.

\subsection{Electricity}

After the sun has set the moonlight can be sufficient to help navigate around Kartong during a clear night. However households and shops rely on candles, battery powered lamps and torches to provide lighting. Cheaply imported torches are sometimes re-purposed to create curious contraptions known as 'local lights': Light emitting diodes extracted from Chinese torches are fastened high up on ceilings or walls from where they connect via electric cables to a wooden box that houses batteries. Other small appliances, mainly radios also use disposable batteries and some people own off-grid solar systems to charge batteries or directly power equipment.

Diesel generators are the main source of electricity for large equipment in Kartong such as sewing machines or televisions used in so called video clubs. This local form of cinema is popular and shows English Premier League football matches and movies. Later this week Halli is going to take some of the younger children to watch a movie in a video club down the road from Sambou-Kunda.

For now generators are important for electricity production in Kartong but things are changing. Last week, just in time for koriteh, the first 19 households including parts of Sambou-Kunda were connected to the national grid. That afternoon Amadou Bansang, who is an electrician by trade, worked with Kartonka Sulayman Manneh to connect the cables to the pay-as-you-go meter. He had previously laid all the internal cabling, installed light switches, sockets and put in energy efficient light bulbs. The system is locally referred to as 'cash power' but Bah-Musa is unsure how one can know when the money needs topping up. It will take some time for people to get used to the new system. The nearest place to get more credit is in Gunjur but perhaps that will change as more households in Kartong are connected.

The grid electricity for Kartong comes from a heavy fuel oil powered generator in Brikama. Petroleum products for electricity generation and motorised transport are imported into The Gambia. Growing consumption of grid electricity in Kartong is therefore likely to further cement dependence on imported fossil fuel resources and thereby leads to economic vulnerabilities of Kartonkas whose livelihoods increasingly rely on it.

The grid infrastructure enters Kartong running south along the Kombo Coastal Road from where it spreads to a number of side streets. However, closer examination illustrates that large parts of the settlement area including Tengo Kuruba are not covered by the electricity infrastructure (Fig. 7).

The area in Kartong that is currently not covered by grid infrastructure largely matches the area that (until recently) was also not connected to the local water distribution network. It could therefore be argued that the limited coverage of grid infrastructure is exacerbating already existing inequalities between older and more recently established parts of Kartong.

Households have to a pay a connection charge of D3,000 if they apply now which will later rise to D6,000. Someone who is employed in the tourist industry may earn up to D3,500 per month though this income is shared with his or her wider family leaving little to the immediate household. As such even D3,000 is too much for some families to afford and especially during the rainy season when income tends to be low as employment in the tourist sector is suspended. Households already disadvantaged by being too far away from the grid to connect have the additional worry of potentially having to pay higher connection fees when the grid is finally extended to their area. Sankung explains that they managed to pay the fee but 


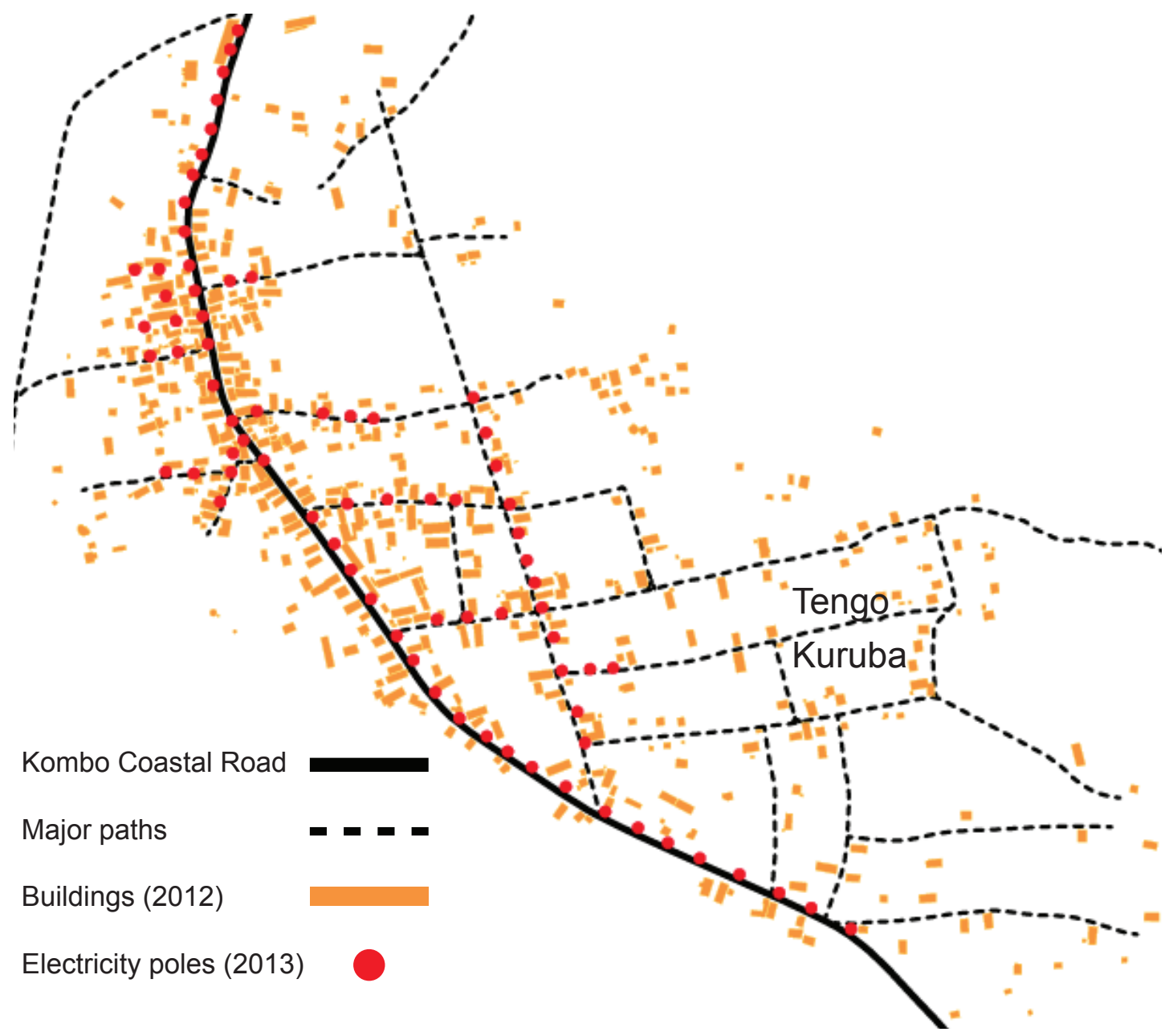

Fig. 7 Kartong grid Distribution of grid infrastructure in Kartong (Source: Author's own work).

not in time to receive a connection at the beginning of August. He and Mai will have to wait until sufficient applications have been made from Kartong for the National Water and Electricity Company to send down another team. In the meantime one end of SambouKunda will continue to rely on battery powered lamps and candles while the other has just installed a television satellite dish. There is a danger of proclaiming benefits to living standards associated with grid electricity whilst ignoring local issues of inequality such as levels of access and quality of service [38].

There are also regional dimensions to electricity access: Kartong is located in the Western Division of The Gambia where the electrification rate was below 20\% until 2010 compared with over $85 \%$ in urban areas surrounding the nation's capital Banjul. Due to significant infrastructure development since then, the electrification rate across the Western Division drastically rose to over $75 \%$ in 2012 [39], though these figures have to be viewed with caution as illustrated above.

The rapid spread of information technologies across the country is a major factor in the increasing demand for electricity. Today Kartong is directly serviced by two mobile phone receptor masts at opposite ends of the settlement area: Gamcel's mast is powered by photovoltaic solar panels, while Africell relies on a diesel generator to power its receptor mast. Local people tend to have two sim cards and sometimes even phones that accommodate both to get better deals and to bridge reception black spots or network disruptions. Buba Demba, a relative of the Sambou's, is spending 
a few days in Kartong. He is a youth worker and is leading a group from across the country on activities during the school holidays. Now that part of Sambou-Kunda is connected to the grid, Buba occasionally comes by with mobile phones that need charging. Most people in Kartong do not yet have access to grid electricity, let alone wall sockets in their homes, but may still need to charge mobile phones and other equipment. This can be done, usually for a fee of D5 at various places across Kartong, including video clubs, the local health centre (which has a solar system), and the generator that powers the Africell phone receptor mast.

However mobile phone usage highlights a gendered barrier to benefits from electricity access. Several generations of women in Kartong might have electricity in their households but are excluded from some of the benefits largely due to their low educational status, specifically their inability to read and write. When one of these women wants to make a phone call, she has to ask someone literate to find the number of the person she wants to speak to in the mobile phone's contact list. When she wants to send a text message, she has to ask someone literate to type it for her and send it to the right person. When she receives a reply she has to trust someone else to read the message out loud for her. This puts illiterate women in a vulnerable position dependent on others to share private conversations. There are also illiterate men in Kartong and in fact it could be argued that barriers to information technologies are generational as much as they are gender related. However, there are significantly more women unable to independently access mobile phone or internet technologies because until recently women's education was sacrificed for that of men.

In Kartong access to computers with internet remains a challenge. Most people will travel to Brikama to visit an internet cafe as the those in Kartong and Gunjur are rarely open. However, there is a new generation of young people with
Facebook accounts accessible from their mobile phones. Family friend Momodou Mbye Jabang describes how he likes to download books and read up on sports news online when he comes to visit. Whilst talking he is navigating between his smart phone and tablet. Both remain a novelty in Kartong but Mbye is providing a sense of things to come.

Around midnight traffic outside SambouKunda quietens down. Soon there will only be occasional packs of wild dogs roaming outside until the call for prayer. Then Bah-Musa and Binta Jassi will quietly leave the house and make their way to the mosque.

\section{Eight months later \\ 5.1 Central water supply}

It is now the dry season and due to a generous donation provided by Dutch sponsors, the piped water system in Kartong has received an upgrade: A new photovoltaic installation has replaced the old panels and drastically increased the capacity to pump water into the storage tank. The original pump had broken and was temporarily replaced by a pump with smaller capacity belonging to Kartonka Foday Juwara. The lining of the storage tank which is currently leaking is due to be replaced before the start of the rainy season. Under-served areas in Kartong will soon be connected to the system. The upgrade means that instead of water taps being opened every few days or even weeks, piped water is now available for $24 \mathrm{~h}$ per day.

In Sambou-Kunda showers and the flush mechanism on toilets which were previously mere ornaments are now in use, though habits of using buckets and cups to wash oneself have not been automatically replaced by using running water from taps and shower heads instead. At household level there are some issues regarding occasional blockages in pipes or lack of pressure. Despite these minor issues, access to water has been completely transformed. 
Through a subsidiary, the Kartong VDC has set up a water committee which is chaired by Kartonka Sanna Tourey. Other committee members include local businessman Kausu Manneh who acts as treasurer, Sankung Sambou who was heavily involved in liaison between Kartong and the donors as well as three women called Bajija Demba, Marta Vega and Binta Sanjang. It was essential to ensure women's voices in the committee as it is largely the responsibility of women to fetch water.

The water committee intends to implement a system to charge for water which will replace the current fee per household that has been difficult to enforce. The aim is to generate money to be used for maintenance and future extensions and ultimately ensure the financial sustainability of the system instead of dependence on donors to resolve any issues arising in the future. A Kartonka who works as programme director at NGO Concern Universal, suggested the money collection system outlined below which is based on a system that was successfully implemented in the town of Lamin.

Since the upgrade of the piped water system, there has been an increase in uptake of private water taps in compounds. There are currently 23 public and 47 private taps, figures which will increase over the coming year. Therefore, households will pay D150 per month per private tap and D200 if they have a private tap and shower. Initially it was intended that public taps would be fitted with locked coin boxes and people should pay D0.5 per twenty litres. However this was difficult to implement and instead money collectors service different areas in Kartong. As well as income for maintenance, the system provides employment opportunities for local people who act as collectors and Dudu Sanyang will soon start to receive remuneration for his services.

Unfortunately $24 \mathrm{~h}$ access to water will be short lived. The drastic expansion of private taps and increase of water consumption over the next year will put a strain on the capacity of the water system. Consequently valves from the tank will only be open between certain hours on most days. As Sanna Tourey and others explain, this situation is unlikely to change unless people become conscious of the amount of water they use, stop wasting the resource by leaving taps running and misuse it to water their gardens. He dreams of adding the abandoned water tank that came with the old windmill that once supplied parts of the settlement area to the new system. He also agrees that household meters would provide an incentive for people to change their behaviour whereas those who currently use less are punished for doing so by those who consume more than their fair share. The alternative to more efficient consumption appears a grid connection to supplement shortfalls in electricity to pump water provided by the photovoltaic installation and limited capacity of the tank. However, this will increase dependence on external fossil fuel resources to supply what is otherwise a common good.

\subsection{Electricity}

Shortly after the first electricity meter was installed in Sambou-Kunda in August 2013, Sankung and Mai were connected to grid electricity. As they are expected to expand into Kanjura's part of the compound once Kanjura and Bintou move, the two families currently share one electricity meter. In the evenings Kanjura and Bintou's television is popular with 'Nollywood', Nigerian movies. Only last week did Badibu and his wife Halli receive their electricity meter and are currently installing sockets and light fittings in different rooms.

Perhaps the most visible difference electricity has brought to Sambou-Kunda and the rest of Kartong are the energy efficient light bulbs that light up rooms both day and night. Along the main road households connected to the grid have placed bulbs that serve as small street lights. Local businesses are benefitting from grid electricity for example by being able to 
run fridges and sell chilled drinks. It will not be long before Mai starts selling small bags of sweet frozen baobab juice to children at the Arabic school where she works, as well as bottles of chilled drinks to people in the neighbourhood (Fig. 8).

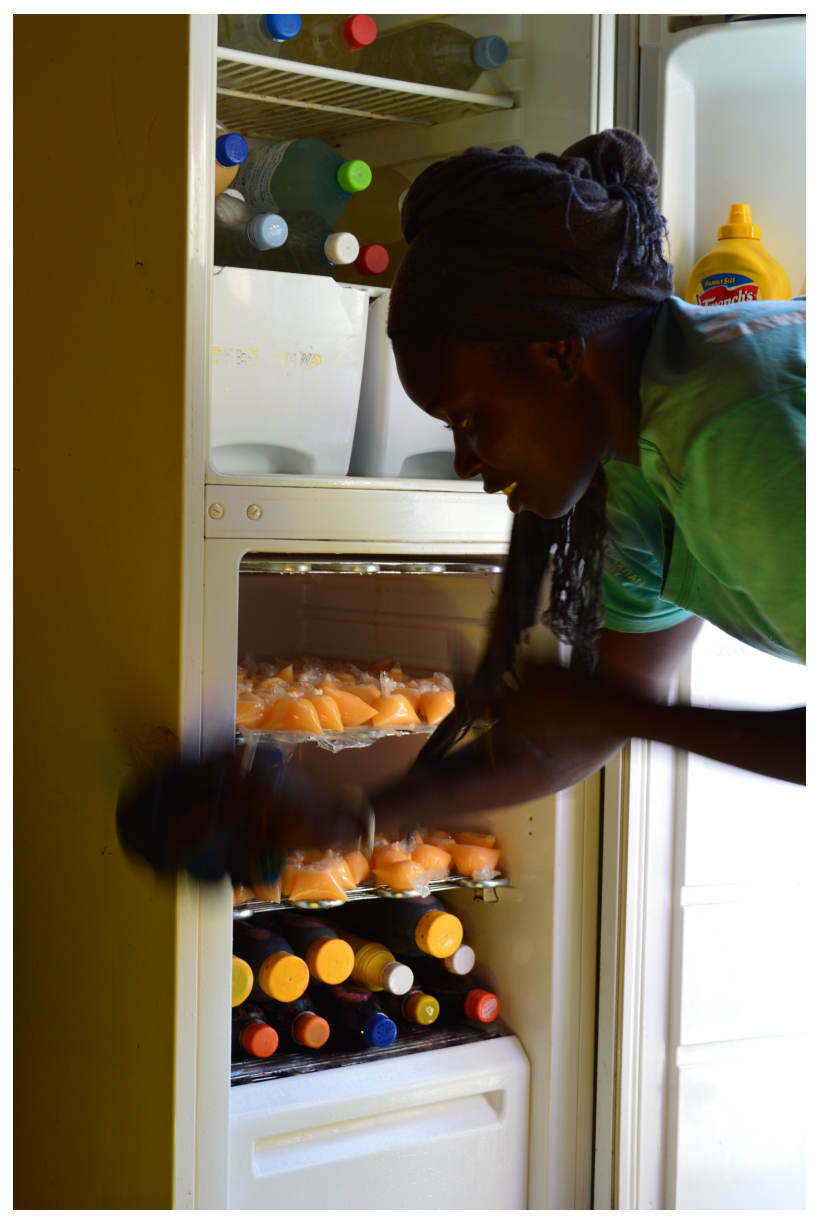

Fig. 8 A new fridge Grid electricity allows Mai Tourey to chill home made drinks. (Source: Author's own photography).

Entirely new businesses will emerge over the coming year which include a Western Union branch. a gaming centre and welder, all located along the Kombo Coastal Road.

The only business adversely affected by the increase in available electricity is the informal mobile phone charging sector which seems to have disappeared entirely as there are more and more places where people charge phones for free.

\section{Discussion}

This research considers energy in the forms commonly used by people in Kartong. It discusses firewood, which is a primary energy fuel, as well as electricity, which is technically a carrier of energy that has been transformed from other energy sources. The research also recognises the importance of physical labour in daily life in Kartong and as such the fuel that sustains it, food. The research attempts to provide holistic insights into Kartong's energy metabolism by situating it in local life and telling stories of energy in Kartong.

The fact that Kartong itself is becoming part of other communities 'hinterland' only comes out in isolated instances. This includes Kanjura's concern about land grabbing from Brikama and Serrekunda as amenities such as electricity are becoming available in Kartong. However, in relation to mineral mining local people do not yet appear to make a connection with the road infrastructure that enables this extraction in the first place. Instead, the Kombo Coastal Road is only associated with benefits around mobility. In other words a holistic critique of the energy transition at local level is missing which suggests a dangerous level of ignorance as Kartong is becoming more dependent on and entangled in 'resource webs.'

However, there are still opportunities within Kartong and the increasing linearity of the energy metabolism, to provide modern energy services for the common good as has long been the case with traditional wood fuel extraction. Though clearly not without its challenges, Kartong's central water supply system highlights that local governance structures and individuals within the community have the capabilities to respond to change for the benefit of the community. As such locally produced energy and local governance could play a bigger role in ensuring that benefits from modern energy services are distributed more equally by building pockets of circular energy metabolism. Continuing this notion of 'circular energy pockets', it may be useful to consider individual sub-tasks associated with a particular type of energy when designing energy strategies. Without losing sight of how 
different task fit into a wider whole, electricity could be considered separately for water supply, local mobile phone receptor masts and household access as opposed to generic electricity access for Kartong. This could highlight particular opportunities for community participation or leadership in the wider analysis of local energy metabolisms.

\section{Conclusion}

Kartong is transitioning towards a linear energy metabolism that is highly dependent on imported fossil fuel resources for motorised transport and grid electricity. While these modern energy services undoubtedly deliver new economic opportunities, overall Kartong is moving away from a circular energy metabolism and thereby also from a circular economic structure in which local people are consumers.

Furthermore, claims to so-called benefits need to be carefully considered. Of particular concern is the inequality of electricity access whose distribution only covers parts of the settlement area. Special consideration also needs to be given to gendered barriers where lower levels of education amongst women can exclude them from some of the benefits. Ignoring the distribution of benefits and the wider economic implications of the ongoing energy transition is likely to exacerbate local inequalities and injustices.

The research demonstrates, that using immersion and mapping to analyse the local energy metabolism, provided a deeper and more holistic understanding of local realities. This challenges the notion of top-down approaches that run the risk of exacerbating local inequalities and economic dependence by failing to understand human dimensions of contexts in which they seek to support sustainable development.

\section{References}

[1] Girardet, H. (1999) Creating Sustainable Cities. Schumacher Briefing, no. 2. Foxhole, Green Books.
[2] Pickett, S.T.A. (2013) Ecology of the City: a perspective from science. In: McGrath, B. ed. Urban Design Ecologies. Chichester, Wiley, pp.160-169.

[3] McDonough, W. and Braungart, M. (2002) Cradle to Cradle: remaking the way we make things. $1 \mathrm{st}$ ed. New York, North Point Press.

[4] Schumacher, E.F. (1993) Small is Beautiful: a study of economics as if people mattered. London, Vintage.

[5] Barry, J. (2015) Green Political Economy: beyond orthodox undifferentiated economic growth as a permanent feature of the economy. In: Gabrielson, T. et al. eds. Oxford Handbook of Environmental Political Theory. Oxford, Oxford University Press, pp.304-317.

[6] Shiva, V. (2013) The Commons: the grounds of democracy and sustenance. In: Ricoveri, G. Nature For Sale: the commons versus commodities. London, Pluto Press.

[7] Ashden Awards (2010) Case study summary: Cooperative Cooperativa de Energia e Desenvolvimento Rural do Médio Uruguai Ltda. (CRELUZ), Brazil. London, Ashden Awards.

[8] Schiffer, A. (2014) From remote island grids to urban solar co-operatives. Edinburgh, Friends of the Earth Scotland.

[9] Roberts, J., Bodman, F. and Rybski, R. (2014). Community Power: Model Legal Frameworks for Citizen-owned Renewable Energy. London, ClientEarth.

[10] Vansintjan, D. (2015) The energy transition to energy democracy: power to the people: final results oriented report of the REScoop 20-20-20 Intelligent Energy Europe project. REScoop 20-20-20.

[11] Müller-Kraenner, S. and Langsdorf, S. (2012) A European Union for Renewable Energy - Policy options for better grids and support schemes. Brussels, Heinrich-Böll-Stiftung, European Union.

[12] Scheer, H. (2010) Der Energethische Imperative: 100 Prozent jetzt: Wie der vollständige Wechsel zu erneuerbaren Energien zu realisieren ist. München, Verlag Antje Kunstmann.

[13] Marriott, J. and Minio-Paluello, M. (2012) The oil road: journeys from the Caspian Sea to the city of London. London, Verso.

[14] Girardet, H. (2008) Cities People Planet: urban development and climate change. 2 nd ed. Chichester, John Wiley \& Sons.

[15] Kennedy, C., Cuddihy, J. and Engel-Yan, J. (2007) The Changing Metabolism of Cities. Journal of Industrial Ecology, 2 (11) pp.43-59.

[16] Chambers, R. (2012) Provocations for development. Warwickshire, Practical Action, p.192. 
[17] Samtez, R. and Maydoney, A. (2003) Storytelling through design. Design Management Journal, 14 (4), pp. 17-34.

[18] Moalosi, R., Popovic, V. and Hickling-Hudson, A. (2010) Culture-orientated product design. International Journal of Technology and Design Education, 20, pp.175-190.

[19] Otto, T. and Smith, R. C. (2010) Design Anthropology: A Distinct Style of Knowing. In: Gunn, W., Otto, T. and Smith, R. C. ed. Design Anthropology: Theory and Practice. London, Bloomsbury, pp.1-29.

[20] England, K. (1994) Getting Personal: reflexivity, positionality, and feminist research. The Professional Geographer, 46 (1), pp.51-63.

[21] Berger, R. (2015) Now I see it, now I don't: researcher's position and reflexivity in qualitative research. Qualitative Research, 15 (2), pp.219-234.

[22] Shacklock, G. and Smyth, J. (1998) Being Reflexive in Critical Education and Social Research. London, Falmer Press, p.7.

[23] Venkatesh, S.A. (2013) The Reflexive Turn: the rise of first-person ethnography. The Sociological Quarterly, 54, pp.3-8.

[24] Chambers, R. (2012) Provocations for development. Warwickshire, Practical Action.

[25] Shea, A. (2012) Designing for Social Change: strategies for community-based design. New York, Princeton Architectural Press, p.13.

[26] Laurel, B. ed. (2003) Design Research: methods and perspectives. Cambridge Massachusetts, MIT Press, p.166

[27] Coffey, A. (1999) The Ethnographic Self: fieldwork and the representation of identify. London, Sage Publications.

[28] Pink, S. (2007) Doing Visual Ethnography Images, media and representation in research. 2 nd ed. London, Sage Publications Ltd.

[29] Brook, R. and Dunn, N. (2013) Urban Maps: Instruments of Narrative and Interpretation in the City. Farnham, Ashgate Publishing Limited.

[30] Access Gambia (n.d.) Kartong - Beach \& Village, Gambia [Internet], Access Gambia Web Directory. Available from: $<$ http://www.accessgambia.com/ information/kartung.html $>$ [Accessed 1 March 2016].

[31] GBOS (2003) Gambia 2003 Population Housing Census - 2003 Census Tables. Serrekunda, Gambia Bureau of Statistics.

[32] Singh, G. et al. (2013) The Gambia: renewables readiness assessment 2013. Abu Dhabi, International Renewable Energy Agency.
[33] Manneh, E. F. (2009) A plea from Kartong. Daily Observer [Internet], 17 June. Available from: $<$ http:// archive.observer.gm/africa/gambia/article/a-plea-fromkartong $>$ [Accessed 1 March 2016].

[34] Robinson, P. (2001) The Gambia. In: Evans, M. I. and Fishpool, L. D. C. ed. Important Bird Areas and Associated Islands: Priority Sites for Conservation. Cambridge, Pisces Publications/ Birdlife International, pp. 357-366.

[35] WHO (2014) Household Air Pollution and Health [Internet], Geneva, World Health Organization. Available from: $<$ http://www.who.int/mediacentre/ factsheets/fs292/en/ $>$ [Accessed 1 March 2016].

[36] Sallah, A. and Williams, C. C., (2011) The illusion of capitalism in contemporary Sub-Saharan Africa: a case study of the Gambia. Foresight, 13 (3), pp.50-63.

[37] Wright, D. R. (2010) The World and a Very Small Place in Africa: A History of Globalization in Niumi, The Gambia. 3rd ed. New York, M.E. Sharpe.

[38] Khandker, S. R. et al. (2014) Who Benefits Most from Rural Electrification? Evidence in India. Energy Journal. 35 (2) April, pp.75-96.

[39] Ceesay, M.L.S (n.d.) The Gambia: new renewable energy law and feed-in-tariff rules. Public Utilities Regulatory Authority.

\section{Acknowledgements}

The author wishes to thank Professor Greg Keeffe and Professor John Barry at Queen's University Belfast for their support and encouragement. The author also thanks the three reviewers who took the time to constructively comment on the work. Also, thank you to Melissa Rezaei and Peter Hamilton for taking the time to share digital information and skills. Finally, the author wishes to thank all Kartonkas without whom this research would not have been possible and especially the Sambou family. Abaraka bake 